\title{
Lipomatous Neoplasm
}

National Cancer Institute

\section{Source}

National Cancer Institute. Lipomatous Neoplasm. NCI Thesaurus. Code C4248.

A benign, intermediate, or malignant mesenchymal neoplasm composed of adipose

(fatty) tissue. 